
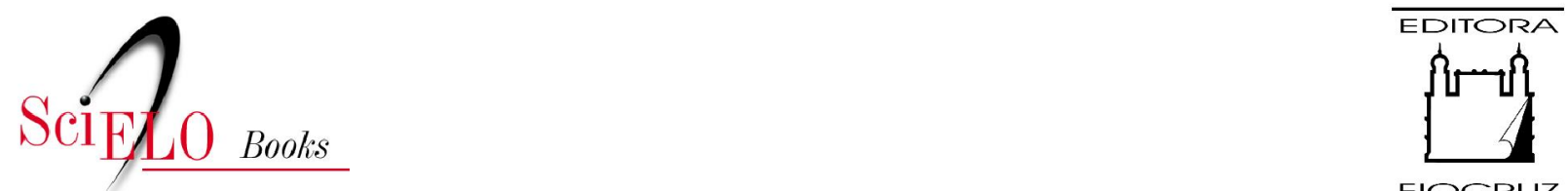

FIOCRUZ

\title{
Os desafios de educar para o novo contexto de leitura, linguagens e produção da informação
}

\author{
Lígia Beatriz Carvalho de Almeida \\ Mariana Pícaro Cerigatto
}

\section{SciELO Books / SciELO Livros / SciELO Libros}

ALMEIDA, L. B. C. and CERIGATTO, M. P. Os desafios de educar para o novo contexto de leitura, linguagens e produção da informação. In: SOUZA, F. M., and ARANHA, S. D. G., orgs.

Interculturalidade, linguagens e formação de professores [online]. Campina Grande: EDUEPB, 2016, pp. 203-230. Ensino e aprendizagem collection, vol. 2. ISBN 978-85-7879-347-0. Available from: doi: $10.7476 / 9788578793470.0010$. Also available in ePUB from: http://books.scielo.org/id/qbsd6/epub/souza-9788578793470.epub.

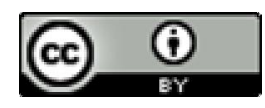

All the contents of this work, except where otherwise noted, is licensed under a Creative Commons Attribution $\underline{4.0 \text { International license. }}$

Todo o conteúdo deste trabalho, exceto quando houver ressalva, é publicado sob a licença Creative Commons Atribição 4.0.

Todo el contenido de esta obra, excepto donde se indique lo contrario, está bajo licencia de la licencia Creative Commons Reconocimento 4.0. 


\title{
OS DESAFIOS DE EDUCAR PARA O NOVO CONTEXTO DE LEITURA, LINGUAGENS E PRODUÇÃO DA INFORMAÇÃO
}

\author{
Lígia Beatriz Carvalho de Almeida (UFCG) \\ Mariana Pícaro Cerigatto (UNESP)
}

\section{Um novo ambiente de linguagens e comunicação}

Após passarmos por fases históricas em que a linguagem oral e escrita foram predominantes em nossa sociedade, na atualidade, a atenção volta-se para a terceira "era" da linguagem, a linguagem digital, com a qual se tem mais contato. Ela é baseada em códigos binários, englobando aspectos da oralidade e da escrita em novos contextos. Em meio a isso, destaca-se, neste texto, a importância de o educador refletir sobre os novos perfis de leitores, sobre suas habilidades diante de novos textos e também as habilidades dos novos produtores de informação, que traz como consequência o pensar novos horizontes e novas perspectivas para a alfabetização necessária ao longo da vida. 
O ponto de partida desta discussão é o necessário entendimento sobre o papel transformador da tecnologia digital na formação de novos leitores e produtores. De acordo com Kenski (2007), ela

[...] rompe as formas narrativas circulares e repetidas da oralidade e com o encaminhamento contínuo e sequencial da escrita, e se apresenta como um novo fenômeno descontínuo, fragmentado e, ao mesmo tempo, dinâmico, aberto e veloz. Deixa de lado a estrutura serial e hierárquica da articulação dos conhecimentos e se abre para o estabelecimento de novas relações entre conteúdos, espaços, tempos e pessoas diferentes (KENSKI, 2007, p.31).

A base da linguagem digital é o hipertexto, "sequências em camadas de documentos interligados, que funcionam como páginas sem numeração e trazem informações variadas sobre determinados assuntos" (KENSKI, 2007, p.32). As misturas de linguagens e mídias (sons, vídeos) formam a hipermídia.

A reconfiguram formas de ler e acessar informações, e a facilidade de navegação, hipermídia e o hipertexto manipulação e liberdade de estrutura, são estímulos para a participação, interação. O poder de seletividade, de decidir o caminho da leitura é bem maior, a "exploração" da realidade informacional se torna mais acessível por meio dos vários recursos disponíveis. 
É no hipertexto que circulam os diversos conteúdos e fontes de informação; é preciso ainda mencionar os novos perfis de leitores e a relação que têm com esses novos conteúdos. O leitor da geração "Y" já não lê da mesma forma que o leitor de gerações antigas, e também diversificou bastante suas fontes de informação por causa das mais variadas possibilidades de produção de conteúdo, agora descentralizada das grandes empresas e veículos de comunicação.

Hoje a biblioteca não é fonte exclusiva de saber e informação, nem a escola o é. Um simples "meme" ${ }^{1}$ na Internet, um vídeo de um canal de um blogueiro no YouTube, um artigo ou notícia escrito em um blog independente de jornalismo são fontes de informação mais acessadas e consumidas pelas novas gerações.

O cenário de linguagens híbridas, que caracteriza o referido contexto, nasce diante o ciberespaço. As matrizes da linguagem (SANTAELLA, 2001) ajudam a compreender o fenômeno da linguagem híbrida no hipertexto. A essa expansão de signos e de linguagens no ciberespaço podemos chamar de "multiplicidade semiótica" (ABREU; MONTEIRO, 2010).

Apesar da evolução de uma diversidade de meios de comunicação, ainda diante da convergência tecnológica e de muitos estudiosos ressaltarem que para cada meio produtor de sentidos existe uma linguagem especial, Santaella (2001) argumenta, recorrendo a Peirce, que só existem três matrizes lógicas da linguagem e pensamento, "que se entrecruzam no estado da comunicação atual,

1 A expressão meme de Internet é usada para descrever um conceito de imagem, vídeo e/ou relacionados ao humor, que se espalha via Internet, conforme Dawkins (1989). 
formando a hipermídia, linguagem não-linear, não-analógica, assentada sobre o hipertexto e podendo estocar informação com mais facilidade" (REGIS, 2002, p.243).

Fazendo isso, segundo Santaella (2001), o propósito não é rotular, mas mapear as possibilidades do pensamento e do conhecimento, através das matrizes que fazem um intermediário entre os conceitos peirceanos e as linguagens manifestas, assim subsidiando a leitura de processos concretos de signos: uma música, uma poesia, um longa metragem, um programa de televisão, e todas as suas misturas que estão sujeitas a ocorrer na hipermídia.

A teoria das matrizes institui as vertentes sonora, visual e verbal, que abrangem a variedade e multiplicidade das formas de linguagens. A partir dessas matrizes instituídas com bases na tradição peirceana e na fenomenologia, todas as combinações e misturas são possíveis, segundo a autora.

Assim, as matrizes da linguagem e pensamento - a sonora, a visual e a verbal - há a correspondência com cada uma das categorias fenomenológicas e da classificação dos signos. De acordo com Santaella (2001), e agora relacionando as matrizes com os tipos de signo, a matriz sonora está para a primeiridade e se relaciona ao ícone; a matriz visual está para a secundidade e é uma questão do índice, já a matriz verbal está para a terceiridade e se refere ao símbolo. Três alicerces classificatórios foram demarcados: o eixo da sintaxe está para a matriz sonora, o eixo da forma aponta para a matriz visual e o eixo do discurso se norteia pela matriz verbal.

Essa caracterização das linguagens em três matrizes (sonora, visual e verbal) fornece subsídio para melhor apreciar e observar de maneira mais ampla e menos limitada as possibilidades de materialização do pensamento 
humano nos novos meios de informação e comunicação e as complexas linguagens, que o aparecimento da hipermídia impõe. Para Regis (2002), Santaella fornece ferramentas e fundamentação peirceana para melhor explorar o campo da linguagem, no atual contexto de produção cultural.

Após classificar as matrizes, Santaella afirma que "as matrizes não são puras. Não há linguagens puras. Apenas a sonoridade alcançaria um certo grau de pureza se o ouvido não fosse tátil e se não se ouvisse com o corpo todo" (SANTAELLA, 2001, p. 371).

Por trás da aparente diversidade dos processos de signos, sistemas de linguagens e mídias nos quais os signos se encarnam e através dos quais circulam, só há três matrizes da linguagem e pensamento. Toda a profusão diferenciada de signos com que convivemos a cada dia, hora e instante de nossa vida, não é senão fruto de misturas sem fim e combinações imprevistas de um número finito de modalidades [...] (SANTAELLA, 2001, p. 411).

Ao sustentar estes argumentos, podemos considerar que a hipermídia abriga uma mistura de linguagens, que geram desafios semióticos de interpretação e significação. Pois, segundo Santaella:

Toda nova linguagem traz consigo novos modos de pensar, agir, sentir. Brotando da convergência 
fenomenológica de todas as linguagens, a hipermídia significa uma síntese inaudita das matrizes da linguagem e pensamento sonoro, visual e verbal com todos os seus desdobramentos e misturas possíveis. Nela estão germinando formas de pensamento heterogêneas mas, ao mesmo tempo, semioticamente convergentes e não-lineares, cujas implicações mentais e existenciais, tanto para o indivíduo quanto para a sociedade, estando apenas começando a apalpar (SANTAELLA, 2004, p.392).

No hipertexto, a hibridização das linguagens é algo muito característico - e foi impulsionada pelo surgimento dos meios elétricos que propiciaram novas formas de linguagem, associadas às novas formas de comunicação (MONTEIRO, 2004). É possível dividir as linguagens híbridas e caracterizar suas misturas, segundo a classificação das matrizes da linguagem. Em Santaella (2001), encontramos a verbal-visual: gesto, "dança-performance", mímica entre outras.; verbal-sonoro: poesia sonora, canto, rádio, literatura oral; visual-sonoro: a dança, computação gráfica; visual-verbal: anúncio publicitário impresso, escritura, poesia, poesia visual, charge, jornal, enciclopédia; sonoro-verbal: canção; sonoro-visual: música instalação, teatro experimental, vídeo.

A hipermídia está embutida na fusão do sonoro-verbal-visual, que também pode contemplar o circo, o teatro, o cinema, a TV. O ciberespaço, portanto, parece reforçar 
o ambiente da hibridização, já que no mesmo espaço as três matrizes do pensamento e da linguagem estão explicitadas, manifestas e estão em constante interação/troca (MONTEIRO, 2004).

Ainda em Monteiro (2004), faz-se um adendo importante e sujeito à reflexão diante da discussão de misturas de linguagens na hipermídia e hipertexto. Ela nos fornece exemplos de como a internet abarca todas as linguagens anteriores. O site é um exemplo de forma digital impossibilitado de acontecer em outro meio, tal como o hipertexto.

Entretanto o site é a manifestação de todas as outras linguagens. $\mathrm{O}$ que existe atrás do site? Enquanto o homem não aprimora essa nova forma, a tendência é transpor tudo o que foi criado antes para o espaço digital, assim como muitos tentam fazer com a dimensão verbal na hipermídia, isto é, usando o paradigma do livro impresso em linguagem HTML (MONTEIRO, 2004, p. 23).

A conjuntura delineada remete ao que McLuhan (1999) já havia chamado a atenção: no "despertar" de uma nova tecnologia, o homem tende a entornar tudo que havia anteriormente produzido neste novo meio. Conforme exemplifica Monteiro (2004), é o caso da televisão, que trouxe o cinema para dentro dela, assim como o cinema fizera com a literatura.

Apesar disso, nesta discussão, o importante a ser salientado não diz respeito somente às possibilidades de 
combinação de linguagens - mas inclui a produção de sentidos e de percepção. E ainda, se pode dizer que, já que toda linguagem está ligada à percepção, os meios híbridos, ao combinarem duas ou mais matrizes da linguagem, "acabam também por estimular ou promover uma mudança na posição relativa dos sentidos" (MONTEIRO, 2004, p.14).

O que conduz ao pensamento de que os modos de ler passam por transformações, e assim surgem também novos tipos de leitores.

\section{Três tipos de leitores: o contemplativo, o movente e o imersivo}

Se existe uma reconfiguração da prática da leitura no hipertexto e novos caminhos trilhados para interagir com estes textos, é justificável que se explane mais sobre as novas formas de ler e os novos leitores que surgem, ainda que resumidamente. Importante salientar que Santaella (2004) foca não somente nas características de perfil dos leitores, mas ressalta as habilidades que os diferem, e as transformações sensórias e cognitivas.

Marins (2009) reforça a importância de estudar o novo perfil de leitores no atual contexto, já que,

[...] é preciso investigar de que maneira o contato com outros meios de circulação da literatura (adaptações cinematográficas, e-books e jogos inspirados a partir de textos literários) influencia a formação de uma nova identidade leitora, 
estabelecendo relações entre meios semióticos e linguagens bastante distintas (MARINS, 2009, p.01).

Para Hall (2005), a identidade cultural, em virtude da globalização, atravessa mudanças. Na mesma linha, a identidade leitora também se transforma, neste mesmo momento histórico.

Segundo Santaella (2004), existem diferentes tipos de leitores. O primeiro tipo, o leitor da era pré-industrial, que lê de forma contemplativa, e meditativo, preza pela apreciação da leitura em uma época do "auge" do livro impresso e da imagem fixa. Já o segundo perfil de leitor - que nasceu em meio a Revolução Industrial e centros urbanos, é classificado pela autora como aquele que agora tem contato com uma leitura de mais misturas sígnicas. A leitura é mais dinâmica, mais híbrida. E o "terceiro tipo de leitor" é fruto do ciberespaço, da virtualidade.

O leitor contemplativo (meditativo), o primeiro, estabelece uma relação mais íntima e individual com a leitura. Isso é reforçado também pelo aspecto e condições históricas em que surge este leitor. "Com a instauração obrigatória do silêncio nas bibliotecas universitárias na Idade Média central, a leitura se fixou definitivamente como um gesto do olho [...]" (SANTAELLA, 2004, p.20-23).

Já o leitor movente (fragmentário) é fruto de um cenário de constante crescimento das cidades. Surge, um leitor de informações mais fragmentadas, movente, que diversifica as formas de ler, em um mundo que a imagem passa a ser cada vez mais frequente. Com o advento tecnológico em expansão, a evolução da imprensa, dos jornais, o surgimento dos cinemas, e a instantaneidade da 
televisão, o novo leitor ainda endossa características do perfil anterior, "contemplativo", mas passa a ser também mais "instável".

O leitor imersivo, o terceiro tipo, é o próprio do mundo virtual. Está habituado a receber e ler novas informações, de variados formatos e linguagens. O trajeto de sua navegação é alinear, multilinear, traçado por ele mesmo. É fruto da multiplicidade de imagens sígnicas, transita pelas redes, pelo ciberespaço, e por aquilo que Santaella (2004) chama de "nós e conexões", "arquiteturas líquidas". Já é integrante "nato" de grandes centros urbanos, subordinados à linguagem transitória, que está sujeita a constantes mudanças e possui uma percepção aguçada.

Para a autora, há habilidades de leitura distintas que habitam neste novo tipo de leitor, diferentes, principalmente, das habilidades do leitor do livro impresso, contemplativo. Segundo a pesquisadora, ele é "um leitor em estado de prontidão, conectando-se entre nós e nexos, num roteiro multilinear, multissequencial e labiríntico que ele próprio ajudou a construir [...]" (SANTAELLA, 2004, p.33).

Machado (2007) chama a atenção para uma postura mais ativa: "[...] em vez de ser um observador distanciado [...] esse novo sujeito é agora implicado no mundo virtual onde está imerso; sua presença ali é ativa, no sentido de desencadeadora de acontecimentos e no sentido também de estar submetida às forças que ali estão em operação (MACHADO, 2007, p.229 - 230).

Assim, pode-se considerar que existe um novo sentido de leitura que hoje se manifesta pela tela do computador e que acarreta mudanças na forma de leitura e escrita, ampliando o foco da educação para o desenvolvimento 
de habilidades voltadas ao domínio das linguagens que se manifestam no hipertexto, também ao considerar as habilidades que os leitores da nova geração já desenvolveram em meio à cultura digital em que convivem. Este leitor coloca em ação diversos mecanismos e habilidades de leituras, muito distintas daquelas que são empregadas pelo leitor de um texto impresso tradicional como o livro, uma revista ou jornal. Também se observa a interatividade com os conteúdos e o poder deste leitor de interferir na produção, se tornando agora um verdadeiro consumidor e ao mesmo tempo produtor de narrativas, imagens, vídeos etc. no cenário da web 2.0 e do hipertexto. A experimentação por parte dos usuários "dos novos meios" é importante para a evolução das novas linguagens. Como toda linguagem está ligada à percepção, os meios híbridos, ao promoverem o encontro dessas linguagens, estimulam uma mudança na percepção dos leitores- e diferentes estruturas perceptivas desencadeiam diferentes mecanismos de compreensão e adquirem diferentes significados.

Além de novos leitores, os novos produtores de informação caracterizam este novo espaço e moldam um novo contexto para a informação e para as narrativas, que passa a ser cada vez mais multimodal ${ }^{2}$.

\section{O produtor de conteúdos da web}

Com o avanço das novas tecnologias, há um aumento na produção, que passa a ser constante, de mensagens textuais, sonoras e visuais em nossas vidas. Assim,

2 Contexto multimodal é aquele que aproveita simultaneamente as diversas linguagens: a sonora, a visual e a verbal. 
"passamos a ter uma relação mais pessoal e dinâmica com a informação e a interação mais frequente com as fontes [...]"(KENSKI, 2007, p.34).

Qualquer um pode informar e ser informado na rede, e estes processos serão melhor "dominados" se competências suficientes forem desenvolvidas. Essa capacidade de participar de forma efetiva em rede define o nível de "empoderamento" de cada pessoa em relação ao seu próprio desenvolvimento e conhecimento. Não são somente as habilidades de comunicação e interação que estão em jogo.

Assim, longe de ser decididamente pós-moderno, o ciberespaço pode surgir como uma espécie de materialização técnica dos ideais modernos. Em particular, a evolução contemporânea da informática constitui uma impressionante realização do objetivo marxista de apropriação dos meios de produção pelos próprios produtores. Hoje, a "produção" consiste essencialmente em simular, em tratar a informação, em criar e difundir (LEVY, 1999, p.227).

A lei da liberação do polo de emissão gera uma remodelagem da cadeia produtiva de mídia, nas etapas de produção, empacotamento e distribuição (PRADO, 2007). Há uma mudança visível no aspecto da comunicação vertical (autoritária, de cima para baixo, unilateral) para a 
comunicação horizontal (mais interatividade entre emissor e receptor).

Mudam-se, com preponderância, os aspectos relacionados ao receptor, que agora vira produtor de conteúdo no cenário da web 2.0. Uma das ferramentas digitais que marcaram essa atuação do receptor como produtor de conteúdo foram os blogs, espaços na internet que intervêm na atividade jornalística, na literatura etc. Como afirma Lemos (2010), os blogs, como canais de publicação, são a oportunidade para que o receptor "realize" seu desejo antes reprimido na cultura de massas: o de ser ator na emissão, de produzir e emitir informação, sem depender de intermediários. E ainda, o mesmo estudioso identifica que este fenômeno está ligado a movimentos da cultura punk, que prega o "faça você mesmo, produza informação". Assim:

A liberação do polo de emissão e as facilidades de manuseio das tecnologias digitais promoveram uma cultura mais participativa, onde todas as pessoas, com mínimos recursos, podem divulgar obras de arte, textos, notícias, filmes e músicas para um número amplo de pessoas conectadas à rede mundialmente (GONÇALVEZ, 2011, p. 81).

Há assim uma significativa mudança entre a "comunicação de um para todos" e a "comunicação de todos para todos". "A lógica da cibercultura é a do "e, e, e..." e não do "ou isso ou aquilo" (LEMOS, 2004, p.18). 
Apesar dessa manifestação, fruto de uma prática sociocultural contemporânea, indicar que se vivencia um relativo "excesso informacional", Lemos (2005) prefere chamar isso de uma situação de "emergência de vozes e discursos, anteriormente reprimidas, em consequência do então existente monopólio de edição da informação pelos meios de comunicação de massa. Aqui a máxima é "tem de tudo na internet", "pode tudo na internet" (LEMOS, 2005, p.2).

Essa transição gera conflitos, pois o papel de comunicador deixa de estar restrito a um grupo midiático, que antes detinha o poder de veicular informação em larga escala. Agora, o cidadão comum também pode produzir informações através das mídias sociais (Facebook, YouTube, blogs etc), o que gera crise no modelo de jornalismo tradicional e na indústria cultural. $\mathrm{O}$ cidadão comum também tem o poder de fazer chegar suas informações a um grande número de pessoas. A mídia tradicional fica mais sujeita a receber críticas, que não são mais possíveis de serem controladas. Outras facetas da informação e dos fatos são mostrados para além do recorte da mídia tradicional.

A liberação do polo da emissão é uma das fundamentais e primeiras características da cultura digital "pós-massiva". O antigo "receptor", visto por muitos teóricos como "passivo", de fácil manipulação, agora passa a ter uma postura ativa bem definida diante das redes. Ele produz e emite sua própria informação, de forma livre e multimodal (por meio de vários formatos midiáticos) e planetária (LEMOS, 2004). Isso é visto facilmente pelas práticas sociocomunicacionais de indivíduos das mais diversas faixas etárias na internet: usuários escrevendo 
blogs, produzindo vídeos, música, criando fóruns e comunidades, e também desenvolvendo softwares e mais ferramentas da web 2.0.

Essas práticas refletem a potência represada pelos meios massivos de comunicação que sempre controlaram o polo da emissão. Editoras, empresas de televisão, jornais e revistas, indústrias da música e do filme controlam a emissão na já tão estudada cultura da comunicação de massa. Na indústria cultural massiva, há um emissor de informação que dirige sua produção para uma massa de receptores, transformada, com alguma sorte, em público. Isto não significa que não havia possibilidades de acesso e produção underground da informação: fanzines, rádios e TVs piratas etc. sempre existiram, mas com alcance bastante limitado. A evolução da tecnologia eletrônico-digital cria uma efervescência, um excesso de informação pela possibilidade de que cada um seja também produtor e emissor de conteúdo. Exceção feita, claro, aos países de regime totalitário/autoritário que buscam controlar e filtrar a rede, cercear a produção, a circulação e o consumo da informação, como é o caso da China (LEMOS, 2009, p.39). 
Lévy reconhece que a liberação do polo de emissão liga-se a um movimento internacional "de jovens ávidos para experimentar, coletivamente, formas de comunicação diferentes daquelas que as mídias clássicas nos propõem" (LÉVY, 1999, p.08). E ainda, admite que o ciberespaço, apesar de acarretar problemas relacionados à informação, abre um novo espaço de comunicação, cabendo aos usuários explorar as potencialidades deste espaço, em diversos âmbitos.

Nas palavras de Lévy:

Não quero de forma alguma dar a impressão de que tudo o que é feito com as redes digitais seja "bom". [...] peço apenas que permaneçamos abertos, benevolentes, receptivos em relação à novidade. Que tentemos compreendê-la, pois a verdadeira questão não é ser contra ou a favor, mas sim reconhecer as mudanças qualitativas na ecologia dos signos, o ambiente inédito que resulta da extensão das novas redes de comunicação para a vida social e cultural. Apenas dessa forma seremos capazes de desenvolver estas novas tecnologias dentro de uma perspectiva humanista (LÉVY, 1999, p.09).

Pensar na liberação do polo de emissão também nos remete a pensar em impactos sociais e políticos. O empoderamento da informação e a capacidade de transmiti-la 
por meio de mídias, como aparelhos celulares, de maneira planetária, fez com que, por exemplo, muitas informações e imagens passassem a circular referentes aos tsunamis, aos atentados em Madrid e em Londres, assim como as manifestações em torno da "Primavera Árabe" - imagens, vídeos e demais informações foram disseminadas por diversas pessoas ao redor do mundo. As guerrilhas urbanas ocorridas em Paris foram não só documentadas - o emissor e transmissor de informação de mídias móveis, de alguma maneira, acabam por virar até prova testemunhal, "como no caso de um indivíduo que filmou, da janela de sua casa, através de um telefone celular, a polícia agredindo jovens da periferia. Esse vídeo, disseminado pela rede, em blogs, aumentou ainda mais a revolta" (LEMOS, 2009, p.40). São os blogs, os podcasts, o Facebook etc. favorecendo a atuação dos chamados "citizen media", ou "mídia do cidadão", plataformas que incentivam o usuário a produzir, distribuir e reciclar conteúdos digitais, fazendo verdadeiras releituras de textos literários, opinando sobre a política, matérias jornalísticas etc. Abre-se campo para a ação dos verdadeiros "cidadãos digitais".

Assim, com a liberação da emissão, temos testemunhas que podem produzir e emitir de forma planetária os diversos tipos de informação. Esses exemplos são comprovações da potência da liberação da emissão na atual cibercultura recombinante. Isto nos leva ao segundo princípio: a conexão (LEMOS, 2009, p. 40). 
Dentro da lei da liberação do polo de emissão, temos o surgimento de novos produtores de informação, que se comunicam principalmente por meio das redes sociais baseando-se em um princípio que rege a cibercultura, o chamado remix - o "conjunto de práticas sociais e comunicacionais de combinações, colagens, cut up de informação a partir de tecnologias digitais" (LEMOS, 2005, p.01). "O remix tem suas bases nas misturas, no sincretismo e no pluralismo cultural e se traduz pela possibilidade de apropriação, de desvio e de criação livre a partir de diversos formatos, modalidades e tecnologias" (GONÇALVEZ, 2011, p.32).

Os remixers combinam e recombinam, modificam as imagens. De acordo com Gonçalvez (2011), o produtor que segue a lógica do remix manipula um conteúdo já existente para criar um novo conteúdo. Os remixers dominam as ferramentas que a tecnologia digital oferece.

\section{As multiliteracias para um novo contexto de leitura e produção da informação}

Esforços têm sido feitos para a valorização do livro, da leitura e das bibliotecas e no combate ao analfabetismo. Um exemplo disso, no Brasil, é o Plano Nacional do Livro e Leitura (PNLL), que traça diretrizes para uma política pública voltada à leitura e ao livro no Brasil, com quatro eixos organizadores: democratização do acesso, fomento à leitura e à formação de mediadores, valorização institucional da leitura e incremento de seu valor simbólico e desenvolvimento da economia do livro (BRASIL, 2014).

Por mais que se pregue que a situação de leitura e acesso aos livros no Brasil é precária, uma pesquisa 
recente, intitulada "Retratos da leitura no Brasil", aponta aumento do número de livros lidos por leitor em 2015, se comparado ao ano de 2011: saltando de 1,85 em 2011, para 2,54 em 2015. A amostra foi de 5.012 entrevistas, mesma quantidade que em 2011, envolvendo a população brasileira, com 5 anos e mais, alfabetizada ou não (INSTITUTO PRÓ-LIVRO, 2016).

Mas, mais do que dados, é importante ficar atento que tipo de leitura, e que tipo de livros vêm sendo mais lidos. Na pesquisa da edição mais atual, a Bíblia segue no topo da lista de livros mais lidos e citados. A seguir, aparecem contos e romances - muitos deles, indicados na escola para o vestibular. Livros "best seller" também são bastante lidos, tais como "A culpa é das estrelas", "A cabana", "O pequeno príncipe", "Cinquenta tons de cinza", entre outros. E a leitura de outros materiais, como jornais, é mais frequente que a leitura de livros propriamente dita.

Ler ainda não é o hábito preferido do brasileiro em seu tempo livre, que elegeu assistir à televisão como passatempo predileto. Usar a internet e o Facebook, Twitter ou Instagram são hábitos que têm crescido entre os leitores pesquisados. O estudo aponta que, de forma geral, o tempo livre dos brasileiros está cada vez mais ocupado por uma variedade de atividades, e o uso da Internet segue ganhando destaque, assim como o acesso e uso de redes sociais.

Um dos dados interessantes diz respeito às atividades relacionadas à leitura que se realiza na internet: para fins de leitura, em primeiro lugar, os leitores responderam que usam a internet para ler notícias e informação em geral; em segundo lugar, usam para estudar, fazer trabalho escolar ou pesquisar temas escolares. Em terceiro lugar, os leitores usam para aprofundar temas de seu interesse. 
Levar em conta esses dados é importante para considerar que, de fato, a internet e seus conteúdos têm sido "lidos" constantemente. De maneira alguma, isso significa dar menos importância para o livro impresso e a leitura tradicional, mas admitir que não são somente essas as únicas formas de ler, os únicos suportes, e nem que a leitura, necessariamente, precise estar associada à obrigação escolar; nem somente a algum tema científico e acadêmico.

É preciso não somente reconhecer novos suportes de leitura, mas também diversos conteúdos também como textos a serem lidos, que exigem habilidades de leitura diferentes. E, também, reconhecer que existem mais formas de interação, e quanto mais possibilidades de formar produtores que dominem habilidades de produção de conteúdo, melhor. Importante ressaltar que a produção de conteúdos não deve estar relacionada apenas ao domínio técnico dos aparatos de comunicação, mas o domínio da linguagem também tem que estar atrelado a uma produção ética.

Descentralizar o eixo verbal e considerar o não verbal, assim como desenvolver a competência leitora/produtora para ler e produzir os mais variados textos é também o que defende o próprio Plano Nacional do Livro e da Leitura: "ao reafirmar a centralidade da palavra escrita, não se desconsidera a validade de outros códigos e linguagens, as tradições orais e as novas textualidades que surgem com as tecnologias digitais" (BRASIL, 2014, p.17). E ainda:

No contexto atual, é imperativo que a leitura seja tratada no diálogo com as diversas tecnologias de gravação, entre as quais o livro se encontra. 
Como defende Renato Janine Ribeiro, a maneira adequada de difundir a leitura no Brasil não é a de sua "tradição", mas aquela que considera que o sujeito contemporâneo só consegue ser interativo com a mídia sendo, ele mesmo, "multimeios", necessitando da leitura para sê-lo. No mundo de hoje, não apenas a prática leitora deve passar pelo uso das tecnologias de informação e comunicação, mas o usuário dessas tecnologias deve desenvolver, por intermédio da família, da escola e de uma sociedade leitora, a prática de leitura. Neste sentido, deve-se ter atenção às questões contemporâneas acerca dos direitos autorais, fortemente impactados pelas novas possibilidades tecnológicas e seus avanços em termos de possibilidade de gravação e cópia (BRASIL, 2014, p. 17).

Assim, hoje, quando se fala de apropriação crítica de informação, temos que considerar a necessidade de alfabetização para as novas formas de ler e produzir textos, ampliando nosso conceito de leitura e do que é ser alfabetizado. Segundo Almeida Júnior (2006), atravessamos uma era em que se perpetua, além do texto escrito, a imagem fixa, a imagem em movimento, e o som. Segundo o autor, as pessoas são analfabetas na leitura dessas outras mídias (e linguagens), por achar que não existe a necessidade de aprendizado dessas linguagens, que é algo 
natural. "Não há uma cartilha para o aprendizado delas. É importante lembrar que elas possuem linguagens próprias, específicas e sua leitura precisa do conhecimento dessas linguagens para se concretizar, para se efetivar" (ALMEIDA JUNIOR, 2006, p.53).

A discussão, portanto, nos remete a expandir o conceito de alfabetização, caminhando para olhar para as multiliteracias, as alfabetizações múltiplas ou multilectoescrituras, que consideram que mudanças locais, mundiais, sociais, culturais e tecnológicas influenciaram os modos de ler, escrever, produzir informação, segundo os autores Anstey e Bull (2007). Assim, não faz mais sentido centrar-se na palavra impressa somente.

El conjunto de herramientas para la lectura y escritura presente en los años cincuenta [...] estaba centrado principalmente en las tecnologías de la letra impresa, es decir, las palabras escritas y leídas. Si bien algunos textos contaban con ilustraciones, diagramas y fotografías, el foco de la enseñanza y el aprendizaje estaba en la interpretación del significado único de una palabra impresa, mientras que se le daba poca importancia al rol, o a la lectura, del entorno ilustrativo o diagramático. De modo similar, se ignoraba la influencia del diseño de página sobre el significado. Este conjunto básico de herramientas de lectura y escritura, dominado 
por la palabra impresa, era útil en un mundo donde los puestos de trabajo eran seguros, generalmente ocupados durante toda la vida, y en los que se requería una serie de habilidades básicas con las tecnologias de ese momento: bolígrafo y papel, o máquina de escribir y papel (ANSTEY; BULL, 2007, p.43).

Por mais que as habilidades múltiplas associadas à capacidade de ler e escrever tenham sido cada vez mais valorizadas no mundo atual, além do fato de que a imagem e o audiovisual têm sido cada vez mais fonte de informação e "matéria prima" de um novo perfil de produtor de informação, observa-se ainda que a imagem e outras linguagens não-verbais têm sido, não poucas vezes, mais utilizadas como instrumento ilustrativo. Para exemplificar esta situação no contexto escolar, Champangnatte e Nunes (2011) analisaram que os professores utilizavam as mídias como recurso ilustrativo aos conteúdos que trabalhavam, servindo apenas como complemento. As atividades envolvendo o audiovisual, por exemplo, não geravam discussões, leitura crítica, nem tampouco questionamentos. "O uso da mídia em sala de aula que mais predominou foi a utilização como ilustração, tanto na utilização do vídeo quanto da internet. Nesse tipo de abordagem, a mídia é usada para exemplificar determinados pontos de um conteúdo trabalhado" (CHAMPANGNATTE; NUNES, 2011, p. 32).

Nesta mesma concepção, um leitor que é "multiliterado", na visão de Anstey e Bull (2007), deve compreender 
a interferência cada vez maior da diversidade social, cultural e linguística na leitura e escrita e nas práticas alfabetizadoras. É ainda capaz de manipular a leitura e escrita de maneira crítica, para participar da sociedade como um cidadão ativo e bem informado. O leitor com múltiplas habilidades de leitura e escrita ainda compreende a tecnologia e o desenvolvimento dos textos multimodais, sabendo como utilizar diferentes tipos de textos e de tecnologias, assim como textos que se valham de sistemas semióticos individuais ou combinados. E, importante: a pessoa "multiliterada" é flexível e compreende que a alfabetização é dinâmica e não estática, e se modificam diante das transformações sociais, culturais e tecnológicas.

Nesse cenário, cabe tanto à escola como a outras instituições formadoras fomentar as novas alfabetizações, valorizando as habilidades de leitura do leitor contemporâneo. Valorizar as leituras ligadas por meio de hiperlinks, não-sequencial, que exigem habilidades para entender o significado não só da palavra impressa, mas do som, do vídeo, diante da tela do computador, do tablete, do celular, podem ser atividades a serem desenvolvidas. A interatividade proporcionada pelos novos meios, os diversos aplicativos e softwares que estimulam a produção de diversos tipos de textos, a gravação de vídeos, o trabalho "transmídia" - de contar a mesma história ou disseminar as mesmas informações em diversos veículos de comunicação, linguagens e plataformas - podem ser meios de produção de conhecimento, assim como meios para se expressar. Dessa forma, escrever um texto impresso não é mais o único caminho. Por exemplo, o aluno pode expressar o que aprendeu fazendo uma história em quadrinhos, 
gravando um vídeo, fazendo um "meme", uma produção remix, entre muitas outras possibilidades.

O alerta é para que o trabalho multimodal na educação valorize as novas tecnologias, linguagens híbridas e diferentes mídias, não se concentrando apenas no desenvolvimento de habilidades técnicas para o uso de mídias e tecnologias. A leitura crítica sobre o uso de uma determinada linguagem, sobre o uso de uma tecnologia, também deve ser levada em consideração.

Enfim, espera-se que o presente texto possa contribuir para: a compreensão do contexto cibernético contemporâneo em que crianças e jovens nasceram imersos, assim como do cenário de alfabetização digital que desafia educadores. Adicionalmente, há o interesse de suscitar a elaboração de novas ideias que explorem à multimodalidade, a produção transmídia, o remix e também incentivem a leitura e a produção textual nas salas de aula, que se apropriem das três matrizes de linguagem.

\section{REFERÊNCIAS}

ABREU, J. G.; MONTEIRO, S. D. Matrizes da linguagem e a organização virtual do conhecimento. Ciência da Informação, Brasília, v.39, n.2, p.9-26, maio/ago., 2010.

ALMEIDA JÚNIOR, O. F.. Bibliotecário escolar: seu perfil, seu fazer. In: ROVILSON, José da Silva; BORTOLIN, Sueli. (Org.). Fazeres cotidianos da biblioteca escolar. São Paulo: Polis, 2006, p.43-54.

BRASIL. Ministério da Cultura. Caderno do Plano Nacional do Livro e Leitura - PNLL: Edição atualizada 
e revisada em 2014. Brasília, DF. Disponível em: <http:/ / www.cultura.gov.br/pnll>. Acesso em: 20 set. 2016.

CHAMPANGNATTE, D. M. O.; NUNES, L. C. A inserção das mídias audiovisuais no contexto escolar. Educação em Revista, Belo Horizonte, v. 27, n.3, p.15-38, dez. 2011. Disponível em: <http://www.scielo.br/pdf/edur/ v27n3/v27n3a02.pdf>. Acesso em: 23 set. 2016.

DAWKINS, Richard. The selfish gene. Oxford: Oxford University Press, 1989.

GONÇALVEZ, R. Conteúdos culturais na cibercultura: um estudo do processo de convergência midiática da obra de Clarah Averbuck. 2011. 103 f. Dissertação (Mestrado) - Curso de Letras, Universidade Federal de São João Del Rei, São João Del Rei, 2011. Disponível em: <http:// www.ufsj.edu.br/portal2-repositorio/File/mestletras/ DISSERTACOES_2/conteudos_culturais_ na_cibercultura.pdf>. Acesso em: 10 set. 2016.

HALL, S. A identidade cultural na pós-modernidade. Trad. Tomaz Tadeu da Silva e Guacira Lopes Louro. 10 ed. Rio de Janeiro: DP\&A, 2005.

INSTITUTO PRÓ-LIVRO.Brasil. Retratos da Leitura no Brasil.4. ed.São Paulo: Ibope Inteligência, 2016. Disponível em: $\quad<$ http://prolivro.org.br/home/images/2016/ Pesquisa_Retratos_da_Leitura_no_Brasil_-_2015.pdf $>$. Acesso em: 03 out. 2016.

KENSKI, V. M. Educação e tecnologias: o novo ritmo da informação. Campinas, São Paulo: Papirus, 2007. 
LEMOS, A. Cibercultura, cultura e identidade. Em direção a uma cultura Copyleft? Contemporânea - Revista de Comunicação e Cultura, Bahia, v.2, n.2, p.09-22, dez. 2004. Semestral. Disponível em: <http://www.portalseer.ufba.br/index.php/contemporaneaposcom/article/ viewFile/3416/2486>. Acesso em: 03 set. 2016.

. Cibercultura e remix. In: Seminário Sentidos e Processos. São Paulo: Itaú Cultural. Ago. 2005. Disponível em: <http://www.facom.ufba.br/ciberpesquisa/andrelemos/remix.pdf >Acesso em: 20 set. 2016.

. Cibercultura como território recombinante. In. TRIVINHO, Eugênio; CAZELOTO, Edilson. A cibercultura e seu espelho: campo de conhecimento emergente e nova vivência humana na era da imersão interativa. São Paulo: ABCiber ; Instituto Itaú Cultural, 2009. p.3851. (ColeçãoABCiber). Disponível em: <http://abciber. org/publicacoes/livro1/a_cibercultura_e_seu_espelho. pdf>Acesso em: 24 set. 2016.

LEVY, P. Cibercultura. São Paulo: Editora 34, 1999.

MACHADO, A. O sujeito na tela: modos de enunciação no cinema e no ciberespaço. São Paulo: Paulus, 2007.

MARINS, L. C. A circulação multimodal e intermidial do texto literário e sua recepção por alunos de letras. In: CONGRESSO DE LEITURA DO BRASIL (COLE), 17., 2009, Campinas. Anais do $\mathbf{1 7}^{\circ}$ COLE. Campinas: Unicamp, 2009. p. 01 - 08. Disponível em: <http://alb. com.br/arquivo-morto/edicoes_anteriores/anais17/ 
txtcompletos/sem16/COLE_977.pdf>. Acesso em: 30 set. 2016.

MCLUHAN, M.. Os meios de comunicação como extensões do homem. São Paulo: Cultrix, 1999.

MONTEIRO, Silvana Drumond. As linguagens e o hipertexto: uma introdução às possibilidades discursivas na forma hipertextual. 2004. 33 f. Dissertação (Doutorado em Comunicação e Semiótica) - Pontifícia Universidade Católica (PUC), São Paulo, 2004. Disponível em: <http:/ / www.pucsp.br/ cimid/8inf/monteiro/linghipe. pdf>. Acesso em: 09 ago. 2016.

PRADO, Luiz Carlos Delorme. Convergência e defesa da concorrência: considerações sobre novos mercados relevantes e riscos de concentração. Conferência Nacional Preparatória de Comunicações. Brasília, 2007.

REGIS, Sônia. Percepção, linguagem e pensamento. Galáxia, São Paulo, n.3, p.241-251, 2002.

SANTAELLA, L. Matrizes de linguagem e pensamento. São Paulo: Iluminuras, 2001.

. Navegar no ciberespaço: o perfil cognitivo do leitor imersivo. São Paulo: Paulus, 2004. 